\title{
EARLY WARNING INDICATORS AND OPTIMAL POLICIES FOR MITIGATING ECONOMIC CRISES: EVIDENCE FROM META-ANALYSIS
}

\author{
Arlyana Abubakar*, G.A. Diah Utari**, and Prayudhi Azwar*** \\ *Director, Bank Indonesia Institute. Email: arlyana@bi.go.id \\ **Deputy Director, Bank Indonesia Representative Office in London. Email: utari@bi.go.id \\ ${ }^{* * *}$ Correponding Author, Assistant Director, Bank Indonesia Institute. Email: yudhi@bi.go.id
}

\begin{abstract}
This study examines the early warning indicators of crises and the optimal policies for mitigating economic crises. Based on meta-analysis of 72 studies, we find that the exchange rate is the most used indicator in detecting crises, and the optimal policies for mitigating crises are monetary and fiscal policies. We further find that besides the exchange rate, the interest rate is a dominant indicator of crises in developed countries. Moreover, the foreign exchange, international reserves and current account are the dominant indicators in developing countries. The evidence for developing countries aligns with the finding that policies addressing external sector performance are preferable to mitigate crises in these countries.
\end{abstract}

Keywords: Economic crisis; Early warning indicators; Crisis management.

JEL Classification: C83; G01; H12.

\author{
Article history: \\ Received : October 21, 2019 \\ Revised : : December 22, 2019 \\ Accepted : March 15, 2020 \\ Available online : April 10, 2020 \\ https://doi.org/10.21098/bemp.v23i2. 1421
}




\section{INTRODUCTION}

This study examines the early warning indicators of crises and the optimal policies to mitigate economic crises. The paper is motivated by the recent development in global Volatility, Uncertainty, Complexity, and Ambiguity (VUCA) that could trigger a series of crises in the future. ${ }^{1}$ The rise in and the interconnectedness of global investment, trade, and digital development increased the level of risk in the financial sector that could precipitate another financial crisis. The OECD (2011) states that the probability of a crisis occurring is rising over time, because of an ever-increasing global economic linkage. Such linkages encouraged higher goods, capital, people, and information mobility. It is now accepted that a crisis can spread more rapidly, leading to high social costs in countries that do not even have a direct relationship with its origin country ( Dullien, Kotte, Márquez, \& Priewe, 2010).

A crisis does not only cause a decrease in economic activity but also a reduction in welfare and an increase in income inequality (Bodea, Houle, \& Kim, 2019). A decline in Gross Domestic Product (GDP) of the same value has a greater sociopolitical impact in low-income countries than in developed countries (United Nations, 2010). The Stiglitz Commission Report (2010) also revealed that in developing countries the contagious effect of the Global Financial Crisis (GFC) of 2008 caused negative externalities, which led to a social crisis because it caused a sharp decline in living standards that were even greater for the poor. Moreover, small open economies will always experience spillover effects from the global economy dynamics (see Warjiyo, 2015). A comprehensive understanding of the economic indicators of crises will help policymakers develop timely and important policies to cushion the economy against future crises.

Likewise, the global economy is not yet fully recovered from the GFC despite the tremendous amount of global liquidity injections. Developing countries with more open capital markets remain more prone to re-tightening of global liquidity and sudden capital reversal (United Nations, 2018). Meanwhile, the recovery process of a severe and prolonged crisis is generally slower because recovery needs gradual steps and faces certain uncertainties (World Bank, 2009). Mervyn King in Elliot (2019) $)^{2}$ argue that past crashes spawned new thinking and reform, but nothing changed since the 2008 banking meltdown.

An economic crisis is basically a natural correction mechanism for inaccuracies in formulating economic policy and management. In other words, the crisis pioneered the formation of new policy reforms (crisis-begets-reform) that are more resilient to crises (Hlaing \& Kakinaka, 2018). An economic crisis usually occurs following countries' overconfidence in seeing existing economic conditions (procyclicality issue) and suboptimal implementation of early warning system mechanisms.

The ability to understand past economic problems and the sharpness in seeing potential future crisis are increasingly important in the formulation of economic policy. According to Karmarkar and Vani (2014), Supriyadi (2014), Hmili and

\footnotetext{
1 See Mack et al. (2016) for an over of the recent development in VUCA.

2 Larry Elliott (2019) "World economy is sleepwalking into a new financial crisis, warns Mervyn King", the Guardian, Sun 20 Oct 2019
} 
Bouraoui (2015), and Al-Assaf (2017), the need for understanding early warning indicators of crises and the need for a thorough understanding of the combination of policies used during crises are more essential now than ever, given the rise in the probability of a crisis. Comprehensive foresight in analyzing economic crisis is deemed necessary at the global, regional, and domestic levels. It is also important to realize that the lessons learned from past crises are necessary but remain inadequate in anticipating future crises. Henceforth, every potential crisis in the future requires more understanding and a well-anticipated policy to be kept at bay (see Karmarkar \& Vani, 2014; Hmili and Bouraoui, 2015).

Several economists investigate the potential early warning indicators of crises (see example, Bucevska, 2011; Frankel \& Saravelos, 2011; Karmarkar \& Vani, 2014). Likewise, several economists also review economic policies that are implemented when anticipating and mitigating crises (see example, Panetta, et al., 2009; Edmonds, et al., 2011). The differences in the source of crises, the initial economic conditions, and in the policy response across countries are widely discussed in the literature (see example, Reinhart \& S. Rogoff, 2008; Claessens \& Kose, 2013). For instance, the Asian financial crisis of 1998 and the GFC of 2008 gained significant attention of the literature.

Our study is motivated by the need for understanding multidimensional and multi-varying behavior of economic crises. Given the recent rise in global uncertainty, it is important to develop a comprehensive and integrative perspective regarding past economic crises in order to preempt future crises (see Juhro \& Iyke, 2019). In this study, we answer the two most important questions about crises: (1) What are the variables commonly used to predict crises? (2) what are the optimal policy measures adopted to mitigate crises? To answer these questions, we use a meta-analysis approach to analyze published peer-reviewed studies.

We find that the exchange rate is the most selected crisis predictor in both developed and developing countries. Apart from the exchange rate, the interest rate is the commonly used crisis predictor in developed countries, whereas the international reserves and current account are the commonly used in developing countries. The evidence for developing countries aligns with the finding that policies addressing external sector performance are more preferred for mitigating crises in these countries. We find that for developed countries, guarantees, macroprudential policies, and international assistances are the dominant policies for mitigating crises. For the combined sample (developed and developing countries), we find that monetary and fiscal policies remain the optimal policies for fighting economic crises.

Our analysis adds to the literature in two ways. Practically, our findings can be used as a reference for stakeholders in implementing crisis management policies. That is, the established early warning predictors alongside the identified optimal policies can be used to predict and to mitigate future crises, by considering previous crisis experiences. Further, the findings can also be exploited to develop an early warning system, business cycle analysis, and various types of surveys in mapping current and expected economic conditions. An innovation of our study is that, unlike prior studies, we exploit the power of meta-analysis to dissect and summarize the rich crisis literature, in order to establish very robust early warning crisis signals and optimal policies for mitigating crises. 
The remainder of this paper is organized as follows. Section II reviews the literature on early warning indicators for detecting crises and the importance of policy coordination. Section III outlines the benchmark meta-analysis approach and the data. Section IV presents the results. Finally, Section V concludes the paper and offers some policy recommendations.

\section{LITERATURE REVEIW}

Reinhart and Rogoff (2009) argue that a crisis occurs because an economy naturally goes through a business cycle, whereby booms and busts are recurring historical patterns. A financial crisis is a disruption in the financial market, whereby adverse selection and moral hazard problems worsen, causing the financial market to run inefficiently (see Phan et al., 2020). Such a condition causes the distribution of funds to be less optimal, reducing economic activity (Mishkin, 2001), which in turn creates a sudden freeze on the interbank market, banking crisis, credit collapse, and severe recession ( Boissay, Collard, \& Smets, 2016). A crisis is difficult to predict because of its complex nature, and thus requires additional narration, especially regarding the triggering factors (Padhan \& Prabheesh, 2019).

Claessens and Kose (2013) classify crises into four types based on the causal factors, namely, (1) currency crises, which include (i) first-generation, inconsistencies between monetary and fiscal policies, (ii) the second generation, the government began to calculate costs and benefits, so that the exchange rate could be protected from speculators, and (iii) the third generation, a crisis occurs due to risk-taking behavior followed by recklessness; (2) domestic and external debt crises caused by a country's inability to pay its domestic and foreign debt; (3) sudden stop crises occur because of a sudden decrease in capital inflow resulting in an output loss, which leads to a recession; and (4) banking crises occur due to several conditions, such as an increase in asset prices, credit booms, increased systemic risk, and regulatory failure. However, in reality, a crisis is often caused by more than one factor. Besides, crises often occur in pairs, and the documented twin crises are currency/banking, debt/currency, and debt-banking crises ( Laeven \& Valencia, 2018).

Figure 1 shows that the currency crisis is the most common type of crisis. The figure further shows that the currency/banking and currency/debt crisis pairs are the most common twin crises, while the banking/debt crisis pair is the least common. In all, the global economy experienced 11 triple crises (i.e. banking/ currency/debt pair) since 1970 (see Figure 1). Table 1 reports some examples of currency crisis based on three generations of currency crisis models.

During the last four decades, the global economic dynamics reflected the impact of developed countries' monetary policy arrangement. The low real interest rate policies taken by the developed countries during the late 1970s, the early 1990s, and the early 2000s caused massive capital inflows toward developing countries, which in turn led to capital vulnerabilities (see Lopez-Mejia, 1999; Kim, 2000: Claessens and Ghosh, 2013).

According to Warjiyo and Juhro (2016), despite experiencing a significant increase in capital flows since the GFC of 2008, foreign capital flows to developing countries in 2015 suffered from net capital outflow. A tight US monetary policy has 


\section{Figure 1.}

Number and Types of Crises (1970-2017)

The figure shows types of crises recorded globally during the 1970 to 2017 period. The three common types of crises are banking, currency, and sovereign debt crises. This information is sourced from Laeven and Valencia (2018).

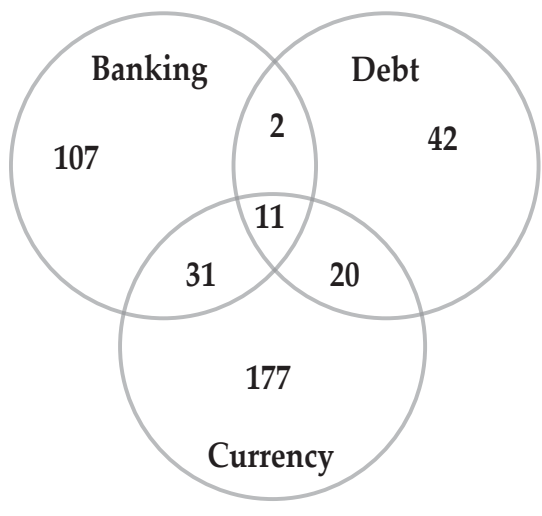

Table 1.

\section{Currency Crisis Based on Generations}

The table shows examples of currency crisis based on three generations of currency crisis models. The 1st generation crisis occurred in 1982, the 2nd from 1992 to 1996, and the 3rd from 1997 to 2001. This information is sourced from Wróblewski (2008).

\begin{tabular}{lcc}
\hline Type of Crisis & Countries & Year \\
\hline $1^{\text {st }}$ Generation Crisis & Argentina, Bolivia, Brazil, Chile, Mexico, Uruguay & 1982 \\
$2^{\text {nd }}$ Generation Crisis & Finland, Spain, Ireland, & $1992-1993$ \\
& Norway, Portugal, Italy, UK & \\
& Mexico & $1994-1995$ \\
& Czech Republic & 1996 \\
$3^{\text {rd }}$ Generation Crisis & Thailand, Malaysia & 1997 \\
& Korea, Philippines, Indonesia & \\
& Russia, Columbia & 1998 \\
& Brazil, Ecuador & 1999 \\
Columbia & 2000 \\
& Turkey & 2001 \\
& Argentina & 2001 \\
\hline
\end{tabular}

detrimental effects on several regions or countries. For instance, the tightening of monetary policy under Volcker's era triggered a severe external debt crisis in Latin America during the 1980 to 1982 period and exacerbated the exchange rate crisis in Mexico during the 1994 to 1996 period (Kose, Nagle, Ohnsorge, \& Sugawara, 2019). Regionally, crises vary, such as the external debt crisis that caused "the lost decade" in Latin America in 1982, the Asian financial crisis in 1998, and the European debt crisis from 2010 to 2012. 
Since the GFC, two forms of globalization, trade and financial integration raised concerns among economic actors because of the possibility of contagion (Padhan \& Prabheesh, 2019). The dynamics of the US economy and its increasing impact on the global and regional economy indicated the level of integration in the global economies and financial markets. Financial integration has a dual impact-the integration of markets acts as a growth catalyst and it increases the possibilities of global shocks to the economies (Prabheesh, Anglingkusumo, \& Juhro, 2020). The financial sector is one of the most vulnerable and forefront areas in any of the past economic crises. A financial meltdown in one country can promptly spillover to other countries, and in turn lead to a full-blown global financial crisis (Edison, Levine, Ricci, \& Sløk, 2002). Similarly, after the collapse of the American financial market in 2008, which led to an instantaneous collapse of the US economy spearheaded the global economic recession, banking crisis, and sovereign debt crisis (Young, 2014).

In the literature, several macroeconomic variables are used as early warning indicators for detecting crises. Kaminsky et al. (1998), using the signaling method, show that international reserves, the real exchange rate, domestic credit/GDP, credit in the public sector, inflation, net exports, exports, money multiplier, real GDP, and budget deficit are important predictors of crises. Similarly, Edison (2000) shows that a crisis occurs by initially sending signals, such as an appreciating real exchange rate, an increasing short-term external debt/reserves and M2/ reserves, a diminishing international reserve, and a decreasing stock price index. Goldstein et al. (2000) find that a currency crisis is signaled through the appreciating of the real exchange rate, a decline in the stock price index and exports, an increase in M1 and $\mathrm{M} 2 /$ reserves, and a decline in international reserves.

From the regional literature, Zhuang and Dowling (2002) argue that crisis signals in several Asian countries include the exchange rates, M2/reserves, foreign liabilities/foreign assets, domestic credit, and asset prices. Meanwhile, Al-Assaf (2017), using Egypt and Jordan dataset, finds that the real exchange rate, M2/ reserves, domestic credit growth, foreign assets/foreign liabilities of the central bank, and export growth are important signals of currency crises. Kamin et al. (2007) identify domestic variables, including real GDP, public sector deficit to GDP, domestic bank loans, M2/reserves, external debt to export, and reserves to short-term debt, as the main early warning signals of a crisis in emerging market countries. They find that the external early warning signals are the real effective exchange rate, export, current account to GDP, foreign direct investment to GDP, terms of trade, US real interest rates, and GDP of industrialized countries. Babecky et al. (2013) find that an increase in money market interest rates, worsening government balance, and a drop in the central bank's foreign exchange reserves usually precede currency crises in developed countries, while Claessens and Kose (2013) show that a rapid increase in asset and credit prices can lead to crises.

There are also studies pinpointing the optimal policies for mitigating economic crises. Chowdhury and Afzal (2015) note that monetary policy is used in minimizing economic fluctuations, while fiscal policy acts as a guarantor of economic stability. When monetary policy fails to stabilize output, fiscal policy is used for countercyclical stabilization (Chowdhury \& Afzal , 2015). An expansive fiscal policy increases aggregate demand, which puts upward pressure on the 
level of inflation. Monetary policy, on the other hand, influences the government in financing the budget deficit by limiting or expanding its funding sources. Weak policies in one area can burden other areas and cause long-term unsustainability. The external sector is at the forefront of almost every crisis. Taylor (2013), for instance, argues that the probability of a crisis increases due to changes in the allocation of capital flows between countries, shifts in interest rates, growth rates, market perceptions, and risks of currencies, while Catão and Milesi-Ferretti (2012) argue that the current account is the main signal a crisis, as it can disrupt access to the capital market, cause poor spreads, and induce defaults. Hence, to overcome the external factor disruption, especially current account imbalances, the literature identifies the coordination of macroeconomic policies (monetary and fiscal) and exchange rate policy, (Bonga-Bonga, 2017). Nickel \& Vanbsteenkiste (2008), for example, find a positive relationship between fiscal policy and current account, suggesting that fiscal policy can be used to shore up current accounts during bad economic times.

Overall, these studies do not unite the early warning signals of crises and policies to mitigate crises. An innovation of our study is that, unlike prior studies, we exploit the power of the meta-analysis to dissect and summarize the rich crisis literature, in order to establish very robust early warning crisis signals and optimal policies for mitigating crises. In what follows, we outline the meta-analysis methodology and our data.

\section{DATA AND METHODOLOGY}

In the literature, there are differences in results and interpretations, and these issues complicate the choice of early warning indicators of crises and policies to mitigate crises. In this case, meta-analysis becomes an alternative approach to reconciling the studies (Stanley, 2001). Meta- analysis is a statistical method developed to analyze and summarize the results of previous studies (Cooper, Hedges, \& Valentine, 2009; Egger \& Smith, 1997). Meta-analysis is also part of a systematic review that seeks to gather empirical evidence based on a predetermined criteria to answer research questions (Haidich, 2010; Basu, 2017). This method can produce a general and integrated conclusion using prior studies, which would minimize bias and enhance comprehension. We apply this method to harmonize the findings of prior studies. However, we need to be more attentive, when designing metaanalysis because it may lead to wrong conclusions and misleading interpretations (Hoffman, 2015). The main advantages of meta-analysis are: (i) it minimize overinterpreting by combining multiple studies; (ii) it is not a hierarchical method, so we do not need to consider sequencing when comparing study; (iii) it can accommodate large numbers of empirical studies; and (iv) it can be used to build a new hypothesis for future research (Lipsey \& Wilson, 2001; Stanley, 2001).

The meta-analysis approach goes through four main stages, namely, problem formulation, data collection, analysis, and result interpretation (Shelby \& Vaske, 2008). The steps for carrying meta-analysis are collect literature/studies, code, collect samples or population of research results, collect the statistical measurements of effect sizes (for conducting meta-regression analysis), and conclude. 
Publication bias is a concern when using this method. Bom and Ligthart (2008) argue that studies that report insignificant results will neither be submitted for publication nor accepted by the editors. That is, journals are more likely to publish studies reporting significant results. To minimize bias, a prospective protocol should be designed by researchers and strictly followed (Finckh \& Tramer, 2008). In addition, monitoring should be carried out together with experts, so that the process and the results are on track (Finckh \& Tramèr, 2008).

In this study, we use the meta-analysis approach to establish the early warning signals of crises and to determine the optimal policies deployed to mitigate crises. Our analysis focused on 72 academic papers. The following criteria informed our choice. First, the type of literature used are quantitative and qualitative research since 1990. Quantitative research will be mainly used to analyze the early crisis predictors. We simplify the identification by focusing on the significant variables in each paper. We then use the qualitative research to analyze the policies implemented by countries to mitigate crises, both in the 1990s crises and the crises in the 2000s. Second, we focus on the approach used in past studies to establish the early warning signals. Most studies use the exchange market pressure index (EMPI) as an dependent variable, with methods such as the signal method, probit, logit, and Markov-switching regressions. Third, we focus on the conclusions of past studies to identify appropriate policies for mitigating crises. Identified in the analysis are conclusions of the reviewed literatures.

As far as crisis measurement is concerned, most of the quantitative studies suggest using the exchange market pressure index (EMPI)-which signals foreign exchange market fluctuation and serves as tension measurement-to analyze crises. The index contains three main weighted components, namely, the exchange rate $(\varepsilon)$, foreign exchange reserves (res), and interest rates (i). Following Eichengreen et al. (1994, 1996), Kaminsky et al. (1998), Choi (2002), Kamin et al.(2007), Caggiano et al. (2013), Comelli (2014), and Al-Assaf (2017), the EMPI equation can be formulated as:

$$
E M P I=\alpha \Delta \varepsilon_{i t}+\theta \Delta r e s_{i t}+\gamma \Delta i_{i t}
$$

Based on empirical studies, the weighting parameters $(\alpha, \theta, \gamma)$ are processed by calculating their standard deviations. Weighting the three components is important since each variable has a different volatility. Note that $\Delta$ denotes the change in each variable (this could be monthly, quarterly, or yearly). To determine a crisis period, we use the difference between the measured index and the calculated crisis threshold. ${ }^{3}$ A period is said to be a crisis when the index exceeds the threshold, and vice versa. That is,

$$
\text { Period } t=\left\{\begin{array}{l}
\text { Crisis, if } E M P I_{t}>\mu_{E M P I}+\beta \sigma_{E M P I} \\
\text { Not crisis, otherwise }
\end{array}\right.
$$

where $\mu$ and $\sigma$ are the mean and standard deviation of the sample, while $\beta$ is the coefficient that shows the severity of the crisis. The greater the value of $\beta$, the

3 Calculated as one or more standard deviations plus the mean of the index (EMPI). 
higher the threshold for the crisis. This parameter affects the ability to detect a crisis because only a severe crisis will be captured. The crisis index is thus a binary variable, which is 0 if the EMPI index value does not exceed the threshold and 1 if the EMPI exceeds the threshold.

Furthermore, based on previous empirical studies, seven candidate variables are selected as early warning crisis indicators and five main policies are selected for further analysis. The early crisis indicator variables are: (i) non-performing loans (NPL); (ii) banking credit, which represents the financial sector; (iii) the interest rate, which represents the monetary sector, and can be measured by real interest rates, lending-deposit rate ratio, money market rates, foreign interest rates (mainly the United States), and differential interest rates; (iv) the external debt measured as total external debt, the ratio of external debt to GDP, the ratio of external debt to exports, the ratio of external debt to gross national income (GNI), short-term external debt, and the ratio of short-term external debt to reserves; (v) current account, represented by the total current account, the ratio of current account to GDP, and the ratio of current account to gross domestic investment; (vi) exchange rate, represented by the real exchange rate and the real effective exchange rate; and (vii) reserves, represented by total foreign exchange reserves, the ratio of reserves to total external debt, the ratio of reserves to GDP, ratio of reserves to total imports, ratio of reserves to $\mathrm{M} 2$, and the ratio of reserves to $\mathrm{M} 1$.

The policies for mitigating crises are: (i) monetary; (ii) fiscal; (iii) real sector; (iv) external sector; and (v) macro-prudential policies. Moreover, we also analyzed guarantees and international assistance, which are part of the main policies for restoring market confidence during crises.

\section{EMPIRICAL RESULTS}

In this section, we discuss the statistically significant early warning crisis predictors and the optimal policies to mitigate crises, as established in prior studies.

\section{A. Exchange Market Pressure Index (EMPI)}

After evaluating the 72 studies, we establish that $30(N=30)$ studies among them used the EMPI method, and hence we pay special attention to this method. The investigation raises several questions concerning common types variables used in the EMPI method to predict crises.

\section{A1. EMPI and its components}

Our investigation shows that 30 studies on crises used the EMPI index to define crises. The main components of the EMPI index (i.e. the predictors of crisis) are summarized in Figures 2.

All the 30 studies used the exchange rate and reserves as components of the EMPI index, while only 10 studies (representing $33.3 \%$ of the studies) used interest rates (see Figure 2). From the combination of the components, we see that 20 studies $(66.7 \%)$ used a combination of exchange rates and foreign exchange reserves, while 10 studies $(33.3 \%)$ used a combination of exchange rates, reserves, and interest rates (see Figure 3). 
Figure 2.

\section{Components of Exchange Market Pressure Index}

This figure shows the percentages of the specific variable used to develop an EMPI based on the survey. This information is sourced from the authors' estimation, $N=30$.

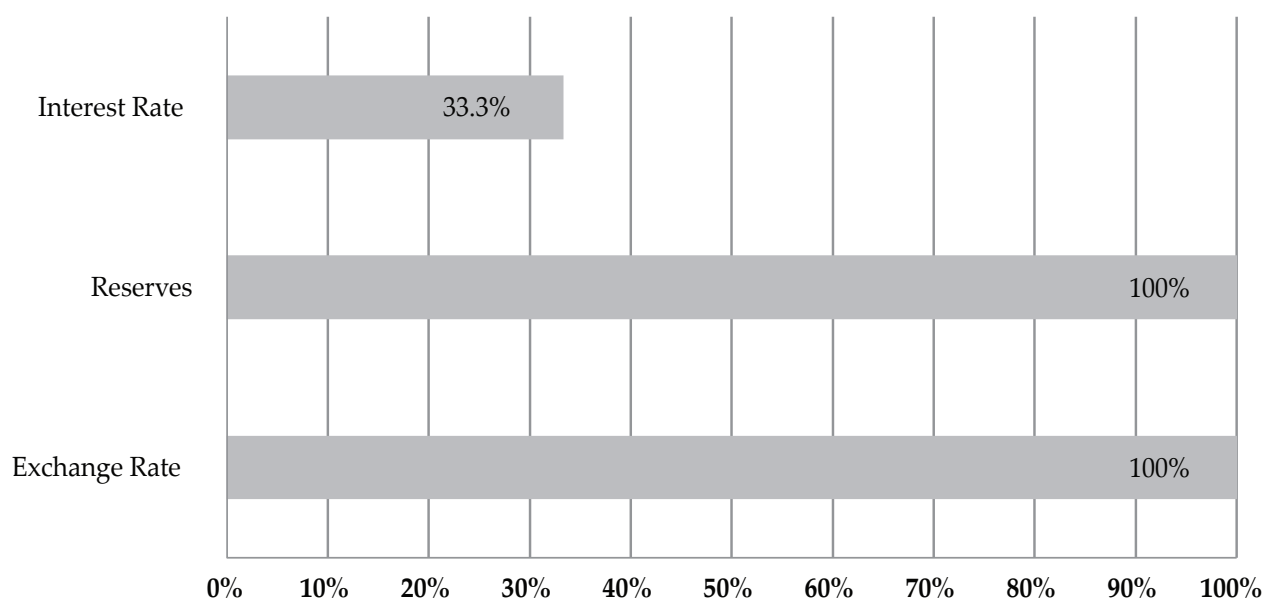

Figure 3.

\section{Combination of EMPI Components}

This figure shows the percentage of the most common variable combination in the survey used to develop an EMPI. This information is sourced from the authors' estimation, $N=30$.

exchange rate, reserves, interest rate

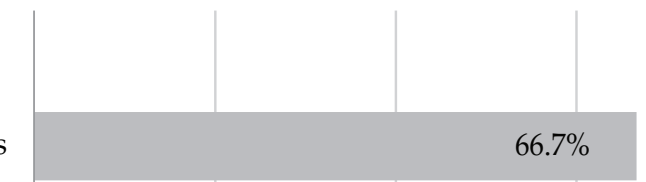

exchange rate, reserves

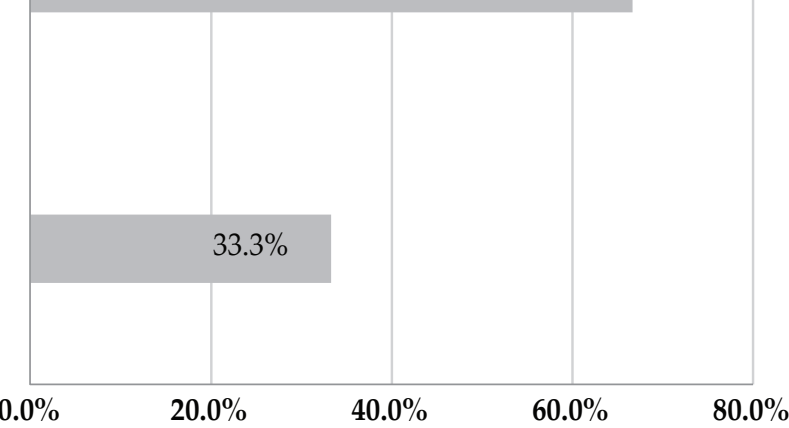

A combination of these components is determined by considering various issues. For instance, if a country is under a flexible exchange rate regime, then foreign exchange, foreign exchange reserves and the exchange rate are included in its EMPI index. When facing external shock pressures, represented by rising exchange rate volatility, the monetary authorities have policy options, such as conducting currency devaluation, increasing the exchange rate, and/or issuing reserves (Fratzscher, 2002). Similarly, during a crisis period, a common step taken by the monetary authority is to monitor changes in the exchange rate because 
it is related to changes in capital flows. In the case of currency crises, monetary authorities usually create a rescue package, such as increasing interest rates or intervening in the market by managing foreign exchange reserves to protect the exchange rate (Choi, 2002). This kind of relationship is explained by Eichengreen et al. (1997). One possible reason for excluding the interest rates, as a component of the EMPI index, is because of the ambiguity about interest rate policy objectives. The interest rate can be used to either control inflation or exchange rates, which is often hard to identify merely from the data.

\section{A.2. Weighting on the EMPI}

The weighting index is an important part of a crisis index. Figure 4 shows the distribution of weights assigned to the EMPI index. The literature typically uses the standard deviation or variance of each variable as weights. The differences between studies lie in the modification of the standard deviation or the variance. Out of the 30 studies, eight $(27 \%)$ used the inverse value of variances as weights, seven $(23 \%)$ used the inverse of the standard deviation, and another seven $(23 \%)$ used the ratio of the standard deviation of interest rates to the standard deviation of the other variables as weights. Furthermore, three studies $(10 \%)$ weighted on the ratio of inverse variable to the total of inverse variables, and the rest $(17 \%)$ did not explain how the weighting was formed.

\section{Figure 4. \\ Various Types of EMPI Weighting}

This figure shows how the weighting on the EMPI commonly formulated. Each EMPI equation uses the one type of weighting. This information is sourced from the authors' estimation, $N=30$.

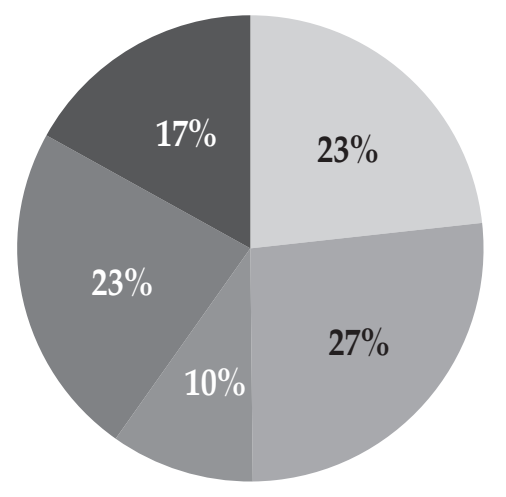

invers of standard deviation

invers of variance

ratio of inverse variable to the total of inverse of crisis index variables

ratio of standard deviation of interest to standard deviation of variable

others

\section{A.3. Standard deviation on the threshold component}

As outlined in Equation (2), the standard deviation of EMPI is an important parameter for establishing the crisis threshold. In previous studies, no specific reasons are given for choosing the standard deviation coefficient, and hence we can conclude that it depends on the discretionary judgment of each researcher. The critical concern in determining the coefficient is that the severity of the crisis level could be unidentified. As a basis for determining the level of the crisis threshold, 
this coefficient is important because the inaccuracy in the selected coefficient level can cause either type I or type II error signals. Setting a relatively low threshold causes economic indicators to produce too many signals, which also increases the chances of type II errors (i.e. false alarm, when the signal appears but a crisis does not occur). Conversely, a threshold that is too high will increase the probability of type I errors (i.e. missed crises, when the signal does not appear, but a crisis occurs).

Figure 5 shows that out of the 30 studies, eight (26.67\%) used a standard deviation of 1.5 , seven $(23.33 \%$ ) used a standard deviation of 3 , five $(16.67 \%)$ used a standard deviation of 2 , while five $(16.67 \%)$ did not state the value of the standard deviation used in their analysis. Statistically, based on the normal distribution, we find that the suggested standard deviation values lie between 2 to 3 (see Figure 5).

\section{Figure 5.}

\section{Coefficient of Standard Deviation}

This figure shows various standard deviation coefficient as one of the main components in determining the threshold. The numbers in the box are the statistical value of overall coefficients. This information is sourced from the authors' estimation, $N=30$.

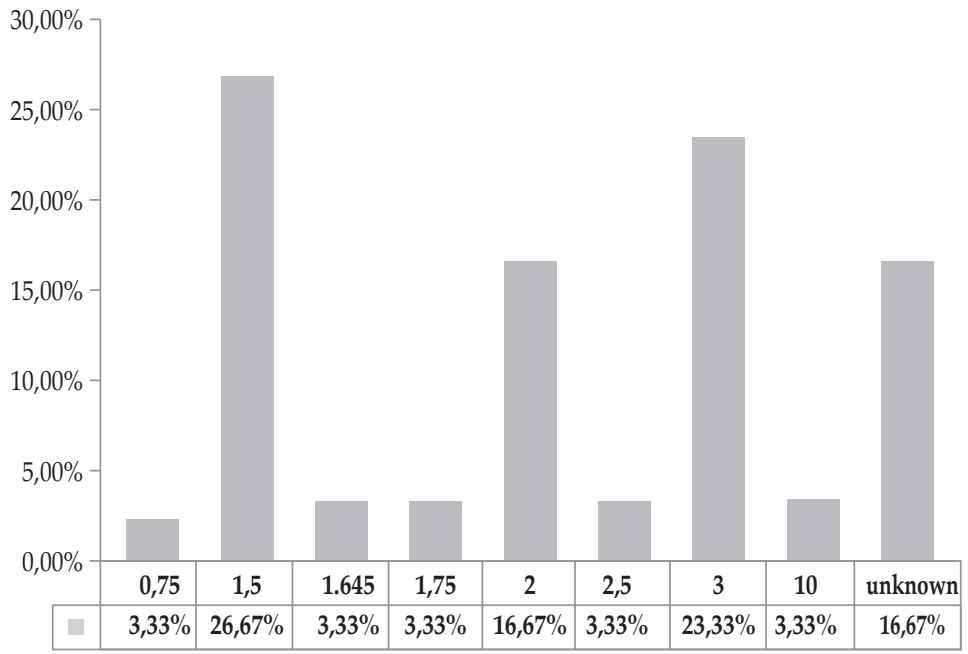

\begin{tabular}{|ll|}
\hline Average & 2,89 \\
Median & 1,87 \\
Min & 0,75 \\
Max & 10 \\
Std Deviation & 2,95 \\
& \\
Variance & 8,69 \\
\hline
\end{tabular}

\section{B. Early Crisis Predictors}

B1. The early warning indicators for the entire sample

Theoretically and empirically, various variables can explain economic crises (see Ramskogler, 2015). Figure 6 shows the variables identified as the early warning indicator crises based on quantitative studies using the signal method, probit, logit, and Markov-switching regressions.

Using EMPI as the dependent variable, the exchange rate is the most selected early warning indicator of crises (i.e. it appears in $90 \%$ of the studies). This could be because the exchange rate is one of the main indicators used to monitor a country's speculative pressures as it reflects the level of market confidence (see Edison, 2000). The more volatile the exchange rate and interest rates are, the higher the risk of a country's financial institutions (Edison, 2000). 


\section{Figure 6.}

\section{Early Indicators for Predicting Crisis Based on All Sample Countries}

This figure illustrates the numbers of indicators that are statistically significant as the early crisis predictor in the survey, without distinguishing the country's characteristics. This information is sourced from the authors' estimation, $N=40$.

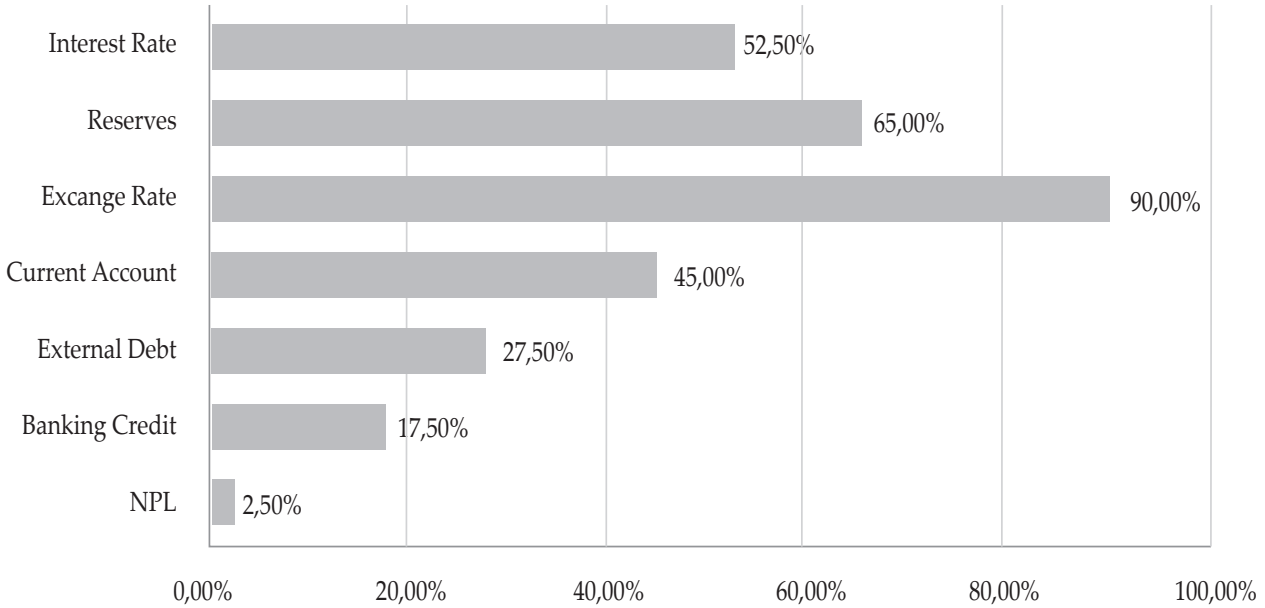

The rationale for choosing the exchange rate as an early warning indicator of crisis also has to do with the exchange rate regime pursued by a given country. The exchange rate regime plays an important role in determining the direction of the economy. For countries that apply fixed exchange rates, their financial authorities always must manage their policies in order to maintain exchange rates at the desired level. Reserves and interest rates are usually the main policy instruments used to maintain the level of exchange rates in such countries. Meanwhile, countries with floating exchange rates are more resilient to currency crises because market adjustments continuously occur to limit overvaluation pressures. If the financial authority fails to carry out its roles under fixed exchange rate regimes or if the market mechanism fails to properly function under floating exchange rate regimes, excessive overvaluation occurs triggering currency crises.

Frankel \& Rose (1996) find that exchange rates are a significant determinant of a probability of crisis occurrence using a probit model. Other studies, such as Berg and Pattillo (1998), Esquivel and Larrain (1998), Milesi-Ferretti and Razin (1998), Kamin and Babson (1999), Caramazza, et al. (2000), Kamin et al. (2007), and Comelli, (2014), using the probit model, also find that the exchange rate significantly explains the probability of a crisis. Similarly, using the logit model, studies such as Goldfajn and Valdes (1997), Hmili and Bouraoui (2015), and Al-Assaf (2017) find that the exchange rate can predict crises. Meanwhile, using a linear regression model, Sachs et al. (1996), Tomell (1999), and Frankel and Saravelos (2011) find a negative and statistically significant relationship between exchange rates and crises.

Along with the exchange rate, foreign exchange reserves are also widely used as an early warning indicator of crises. The higher the level of foreign exchange reserves of a country, the lower the probability of a currency crisis, since the foreign exchange reserves can be used as a buffer against capital flows instability 
( Allegret \& Allegret-Sallenave, 2018). In other words, foreign exchange reserves are intended as a precautionary motive. In addition, foreign exchange reserves also play important roles, such as (1) giving market confidence that the country is able to fulfill its liabilities, (2) it can reduce the cost of adjustments if there is a disruption in the external sector, (3) financing balance of payments transactions, (4) domestic currency holders, and (5) it is used when the country faces an emergency condition (Dominguez, Hashimoto \& Ito, 2011; and Crispolti \& Tsibouris, 2012).

Based on our meta-analysis, foreign exchange reserves significantly affect the probability of a crisis (65\% of the cases, see Figure 6 ). This is consistent with the literature. Low foreign exchange reserves can increase the probability of a crisis ( see, for example, Frankel \& Rose, 1996; Berg \& Pattillo, 1998; Kaminsky et al., 1998). Moreno (1999) and Woo et al. (2000) used logit regressions and find the same evidence-a decrease in foreign exchange reserves increases the probability of a crisis. An increase in foreign exchange reserves will increase the pressure on the EMPI index by 0.131 (Frankel \& Saravelos, 2011).

Current accounts, especially current account deficits, are risk factors that can predict a crisis. The current account deficit is also positively correlated to the economic performance of a country. Schnatz (1998) argues that a current account deficit indicates an increase in external debt in that the ability to pay back the debt is reduced. Besides, the possibility of speculative attacks will increase along with an increase in current account deficit. In addition, current account deficit can also reflect a worsening trade balance. A country that has a trade deficit will be financed from foreign investment. If at the same time foreign investment suddenly stops, the exchange rate will weaken, thereby, increasing the probability of a crisis. Our meta-analysis shows that current account is an important predictor of a crisis (i.e. $45 \%$ of the cases, see Figure 6), consistent with probit-based studies, such as Berg \& Pattillo (1998); Esquivel (1998); Schnatz (1998); and Kamin, et al. (2007). Corsetti et al. (1998) find that every one unit increase in current account deficit would increase the pressure on the exchange rate by 0.762 units.

Two different conditions mark the role of banking credit in the economy. First, in countries with generally high levels of debt, rising level of credit growth equally increases potential debt problems, especially NPL, in that economic recovery is disrupted. Such a notion echoes Comelli's (2014) study in that it shows the distribution of high credit levels, especially in the private sector, which will increase the probability of a crisis. A high level of NPL is a threat to financial stability because it creates illiquidity and exposes financial system to external risks (see Phan et al., 2020). Moreover, Caggiano et al. (2013) find that when the crisis occurs, especially in low-income countries, it is concerned with the drying up of liquidity in the banking system. Besides, in a productive country with a low level of debt, a high level of credit growth can be used to recover the economy from a crisis.

\section{B2. Early warning indicators for developing countries}

We consider the early warning indicators of crises in developing countries. Figure 7 shows the distribution of these indicators. Based on 18 related studies, the two most dominant variables used in detecting crises are the exchange rate $(94.44 \%)$ 
and foreign exchange reserves (66.67\%). The evidence for the developing country sample is slightly different from that of the entire sample, because external factors including current account, banking credit, and external debt are more widely used as leading indicators of crises for these countries, instead of interest rates. According to Kamin et al. (2007), although external factors contribute less than domestic factors to the probability of a crisis in developing countries, during the actual crisis years, external factors actually contribute to the probability of a crisis.

\section{Figure 7.}

\section{Early Indicators for Predicting Crisis Based on Developing Countries Sample}

This figure illustrates the numbers of indicators that are statistically significant as the early crisis predictor based on the survey in developing countries. This information is sourced from the authors' estimation, $N=18$.

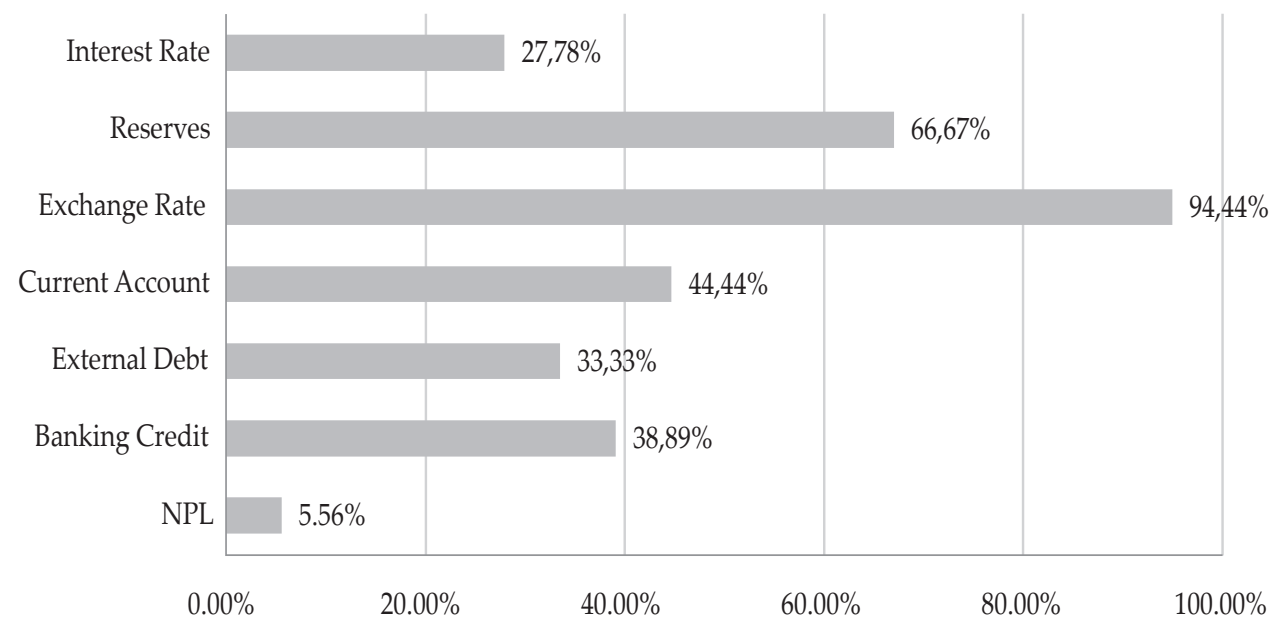

\section{B3. Early warning indicators for developed countries}

We also consider the early warning indicators of crises in developed countries. Figure 8 shows the distribution of these indicators. Based on 20 studies that focused on developed countries, the exchange rate is the commonly used leading indicator of crises (in $85.0 \%$ of the studies), which is followed by interest rates $(75.0 \%)$ and reserves $(60.0 \%)$. When compared with the developing country evidence in Figure 7 , interest rates play a prominent role in detecting crises in developed countries. Conversely, banking credit and NPL are unimportant leading indicators in crisis analysis for developed countries but important in developing country analysis.

Table 2 shows the summary of the early warning indicators for the entire sample, developed countries, developing countries, and others. As far as both the developed and developing countries are concerned, the leading indicators that are mostly used and also statistically significant are exchange rates, foreign exchange reserves, and interest rates (see Table 2). 
Figure 8 .

Early Indicators for Predicting Crisis Based on Developed Countries Sample

This figure illustrates the number of indicators that are statistically significant as the early crisis predictor based on the survey in developed countries. This information is sourced from the authors' estimation, $N=20$.

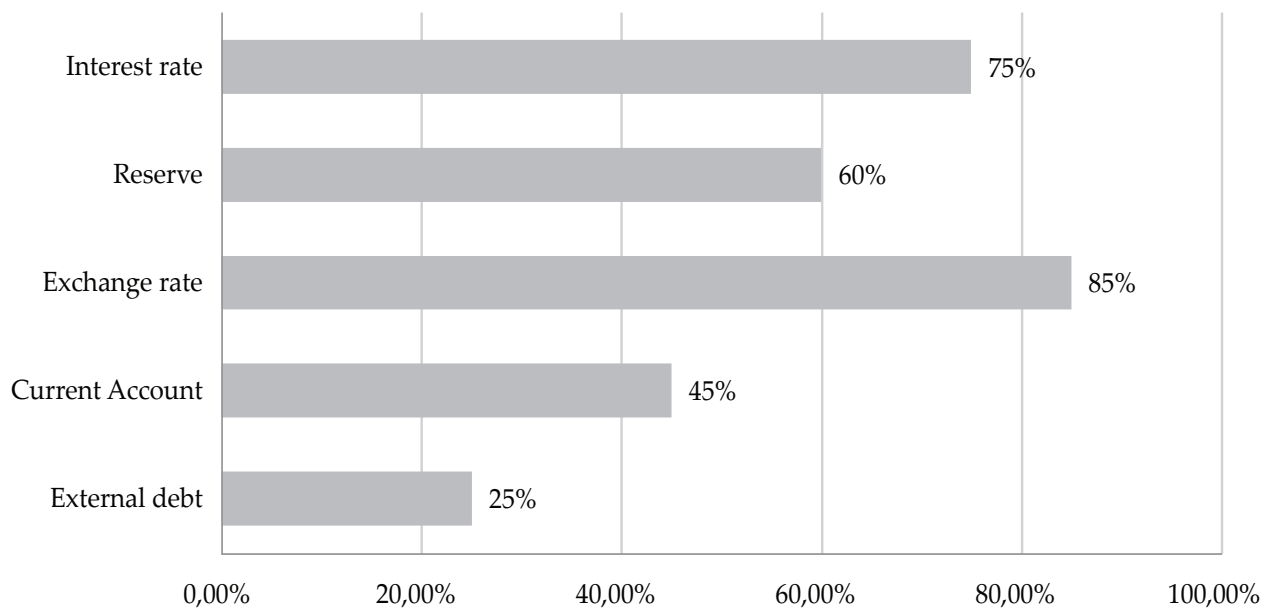

Table 2.

A Summary of Leading Indicator

\begin{tabular}{lcccc}
\hline & All & $\begin{array}{c}\text { Developed } \\
\text { countries }\end{array}$ & $\begin{array}{c}\text { Developing } \\
\text { countries }\end{array}$ & Others \\
\hline 1. Amount Studies & 40 & 20 & 18 & 2 \\
2. Indicator to detect crisis & & & & \\
a. Exchange rates & $90 \%$ & $85.00 \%$ & $94.44 \%$ & $100 \%$ \\
$\quad$ - RER & $66.67 \%$ & $68.75 \%$ & $64.71 \%$ & $100 \%$ \\
$\quad$ - REER & $33.33 \%$ & $37.50 \%$ & $35.29 \%$ & $0.00 \%$ \\
b. Current Account & $45 \%$ & $45.00 \%$ & $44.44 \%$ & $50.00 \%$ \\
- Total current account & $33.33 \%$ & $55.56 \%$ & $12.50 \%$ & $0.00 \%$ \\
- Current account/GDP & $61.11 \%$ & $33.33 \%$ & $87.50 \%$ & $100 \%$ \\
$\quad$ - Others & $5.56 \%$ & $11.11 \%$ & $0.00 \%$ & $0.00 \%$ \\
c. External debt & $27.50 \%$ & $25.00 \%$ & $33.33 \%$ & $0.00 \%$ \\
$\quad$ - Total external debt & $36.36 \%$ & $33.33 \%$ & $50.00 \%$ & $0.00 \%$ \\
- Short term debt/reserves & $27.27 \%$ & $50.00 \%$ & $0.00 \%$ & $0.00 \%$ \\
- Others & $36.36 \%$ & $16.67 \%$ & $50.00 \%$ & $0.00 \%$ \\
d. Foreign exchange reserves & $65.00 \%$ & $60.00 \%$ & $66.67 \%$ & $100 \%$ \\
- Total reserves & $53.85 \%$ & $81.81 \%$ & $25.00 \%$ & $100 \%$ \\
- Reserves/import & $15.36 \%$ & $0.00 \%$ & $33.33 \%$ & $0.00 \%$ \\
- Reserves/external debt & $11.54 \%$ & $9.09 \%$ & $16.70 \%$ & $0.00 \%$ \\
- Others & $19.23 \%$ & $18.18 \%$ & $25.00 \%$ & $0.00 \%$ \\
\hline
\end{tabular}


Table 2.

A Summary of Leading Indicator (Continued)

\begin{tabular}{lcccc}
\hline & All & $\begin{array}{c}\text { Developed } \\
\text { countries }\end{array}$ & $\begin{array}{c}\text { Developing } \\
\text { countries }\end{array}$ & Others \\
\hline e. Banking credit & $17.50 \%$ & $0.00 \%$ & $38.89 \%$ & $0.00 \%$ \\
- Credit growth & $42.86 \%$ & $0.00 \%$ & $42.86 \%$ & $0.00 \%$ \\
- Credit to private non-financial sector/GDP & $28.57 \%$ & $0.00 \%$ & $28.57 \%$ & $0.00 \%$ \\
- Others & $28.57 \%$ & $0.00 \%$ & $28.57 \%$ & $0.00 \%$ \\
f. NPL/total banking asset & $2.50 \%$ & $0.00 \%$ & $5.56 \%$ & $0.00 \%$ \\
g. Interest rates & $52.50 \%$ & $75.00 \%$ & $27.78 \%$ & $0.00 \%$ \\
- Foreign interest rates & $42.86 \%$ & $30.77 \%$ & $100 \%$ & $0.00 \%$ \\
- Real interest rates & $23.81 \%$ & $38.46 \%$ & $0.00 \%$ & $0.00 \%$ \\
- Differential interest rates & $14.29 \%$ & $23.08 \%$ & $0.00 \%$ & $0.00 \%$ \\
- Money market interest rates & $9.52 \%$ & $15.38 \%$ & $0.00 \%$ & $0.00 \%$ \\
- Others & $9.52 \%$ & $7.69 \%$ & $0.00 \%$ & $0.00 \%$ \\
\hline
\end{tabular}

\section{Policies for Mitigating Crises}

Several countries implemented various policies to deal with crises. Figure 9 shows that, out of 41 studies, $56.10 \%$ state that monetary policy was implemented to deal with crises, followed by fiscal policy $(48.78 \%)$, applied guarantee $(34.15 \%)$, international assistance (14.63\%), external policy $(17.07 \%)$, macro-prudential (17.07\%), and other policies (17.07).

\section{Figure 9.}

\section{Policy Mitigation in All Country Samples}

This figure illustrates the policies that are explicitly and implicitly mentioned in the survey to mitigate crisis both in developed and developing countries. This information is sourced from the authors' estimation, $N=41$.

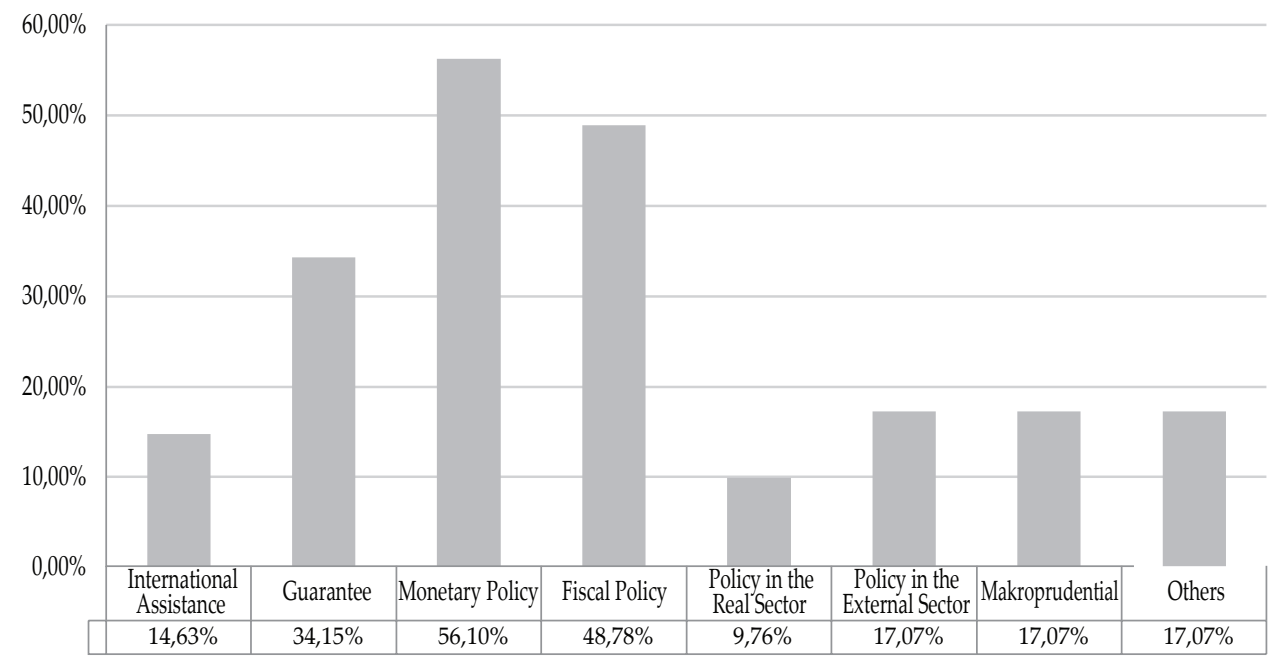


Figure 10 decomposes the policies used to combat crises in developed and developing countries. Out of the 41 studies, 11 discussed the policies pursued in developing countries, 27 discussed the policies pursued in developed countries, while the rest are unspecified.

Figure 10.

Policies Pursued by Developing and Developed Countries to Mitigate Crises

The two figures below illustrate the policies that are applied to mitigate the crisis, distinguishing developing from developed countries.
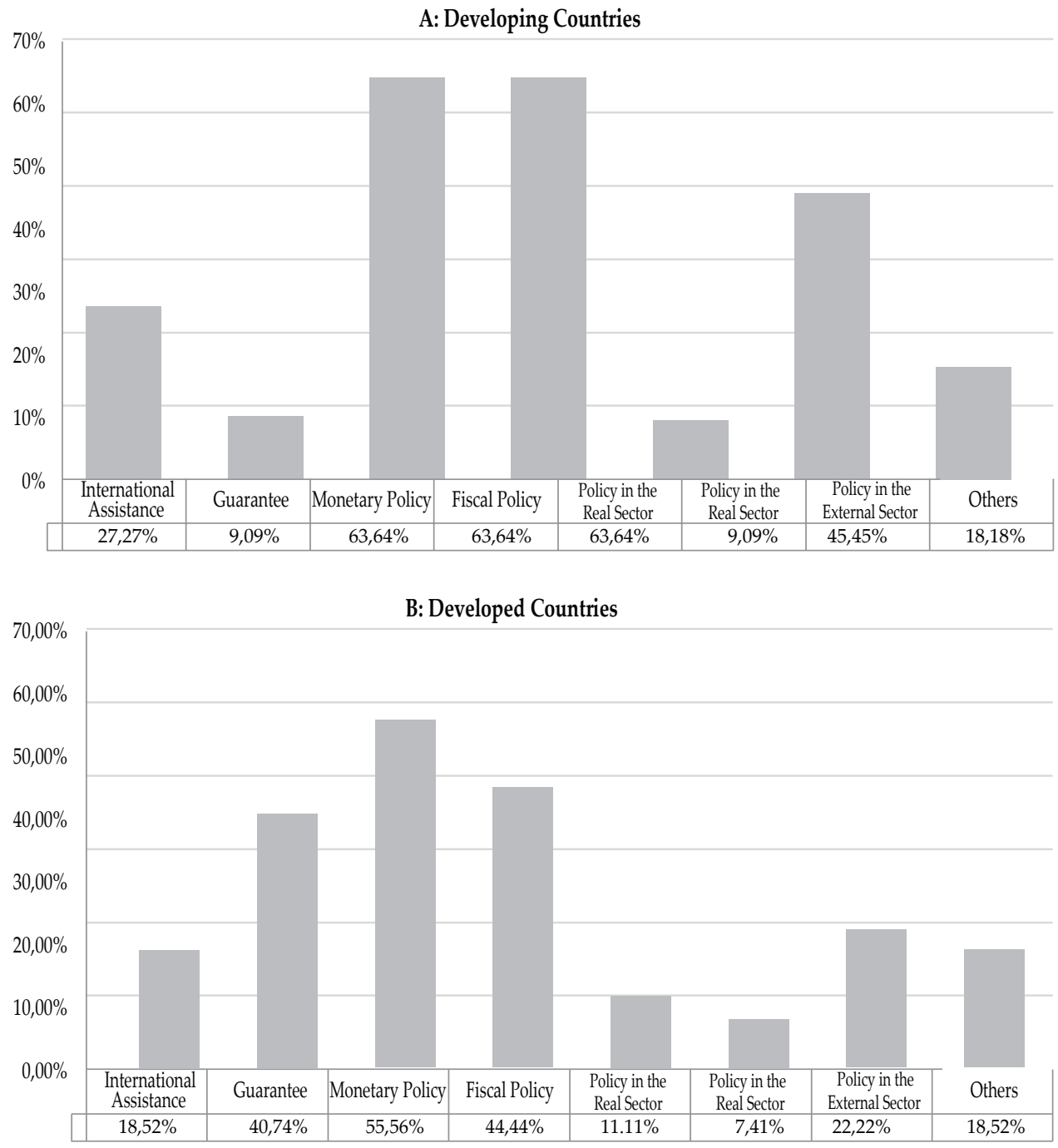

Table 3 summarizes the distribution (proportion) of the policies to mitigate crises by developed and developing countries. The results suggest that monetary policy is the most dominant policy in crisis management in the entire sample, 
as well as the developing and developed country subsamples. This dominance is explained by the fact that: 1) the financial sector plays an important role in the economy, and responds to the central bank monetary stance; and 2) the execution of monetary policy is faster than that of fiscal policy, which requires legislative approval before implementation.

The same monetary response to a financial crisis can have different effects on different economies. In flexible economies - that are characterized by high substitution possibilities among factors of production, and low diminishing returns - an interest rate cut will lead to economic expansion, while in relatively inflexible economies, it can exacerbate the recession (Christiano, Gust, \& Roldos, 2004).

Table 3.

A Summary of Crisis Policy Implementation

\begin{tabular}{lcccc}
\hline & All & $\begin{array}{c}\text { Developed } \\
\text { Countries }\end{array}$ & $\begin{array}{c}\text { Developing } \\
\text { Countries }\end{array}$ & Others \\
\hline $\begin{array}{l}\text { 1. Amount Studies } \\
\text { 2. Types of Policies }\end{array}$ & 41 & 27 & 11 & 3 \\
a. Monetary Policy & $56.10 \%$ & $55.56 \%$ & $63.64 \%$ & $33.33 \%$ \\
b. Fiscal Policy & $48.78 \%$ & $44.44 \%$ & $63.64 \%$ & $63.64 \%$ \\
c. Policies in External Sector & $17.07 \%$ & $7.41 \%$ & $45.45 \%$ & $0.00 \%$ \\
d. Policies in Real Sector & $17.07 \%$ & $11.11 \%$ & $9.09 \%$ & $0.00 \%$ \\
e. Guarantee & $34.15 \%$ & $40.74 \%$ & $9.09 \%$ & $66.67 \%$ \\
f. International Assistance & $14.63 \%$ & $18.52 \%$ & $27.27 \%$ & $0.00 \%$ \\
g. Macroprudential & $17.07 \%$ & $22.22 \%$ & $0.00 \%$ & $33.33 \%$ \\
h. Others & $17.07 \%$ & $18.52 \%$ & $18.18 \%$ & $0.00 \%$ \\
\hline
\end{tabular}

Another policy that is equally widely applied to mitigate crises, based on the entire sample, is fiscal policy. It is implemented to bring coordination between monetary authorities and the government. Since a crisis can affect other areas apart from the financial sector, such as the social and political aspects, the handling of a crisis can no longer be left to the central bank. The involvement of the government, as the fiscal authority is crucial, especially in minimizing the impact of a crisis on the real sector. The government's involvement is necessary to indicate political support for all policies implemented in the country. Another reason is that crisis management often requires a large amount of money, something that the central bank is not able to entirely accomplish without compromising its monetary policies. Therefore, budget support from the government is required to optimize the implementation of central bank policies. Bech et al. (2012) state that a fiscal policy that is implemented during an economic decline can accelerate the recovery process without reducing the effectiveness of the monetary policy. Furceri and Mourougane (2009) explain that the temporarily, timely, and targeted fiscal stimulus may be applied optimally in countries where the effects of the financial crisis are potentially deep. 
Although most of the countries applied monetary and fiscal policies to overcome crises, the effectiveness of these two is still debatable. Boorman (2009), for instance, argues that there are doubts about the power of tax cuts in the US and China's stimulus packages to spur spending. Boorman (2009) finds that, in the US, a substantial portion of the tax cuts has little impact on spending while, in China, the package seemed to stimulate investment and if it created additional export capacity, global imbalances may worsen. Regarding the new era of monetary policy, Edmonds et al. (2011) state that, as quantitative easing is an unusual form of policy (unconventional monetary policy), it is difficult to estimate the extent of quantitative easing required to stimulate the economy to generate the expected effects.

In developed countries, assistance from international and regional financial institutions (e.g., the International Monetary Fund and European System of Financial Supervision) plays an important role in helping stabilize economic conditions during crises. Perhaps, institutional structures and economic conditions in developed countries are relatively better built than those in developing countries to mitigate crises. As a result, developed countries may find it easier to access international assistance. In addition, developed countries could also obtain foreign loans using their own currencies, thus reducing the risk of exchange rates or currency mismatch (Eichengreen, Hausmann \& Panizza, 2003).

Our meta-analysis indicates that while policies to provide guarantees during a crisis are widely practiced in both developed and developing countries, such policies are more frequent in developed countries because of the availability of funds and liquidity, which are relatively better than developing countries. In contrast, crises in developing countries are generally accompanied by massive capital outflows, which cause deeper exchange rate depreciation and significantly reduce foreign exchange reserves. It is then appropriate that policies in developing economies need to be more direct in strengthening the external sector, such as encouraging exports, interventions in the exchange rate market, and better management of foreign exchange reserves.

In summary, monetary policies are the commonly used policies in both developed and developing countries to fight crises. While both developed and developing countries tend to favor fiscal policies as a complement to monetary policies but developing countries deploy fiscal policies more when combating crises. Besides, assistances and guarantees are also popular policies for mitigating crises, particularly in developed countries. To establish the best policies implemented by countries during crises, our meta-analysis focuses on the crises that occurred during the 1990s and 2000s. Thus, further research should be undertaken to address the specific policies used during earlier periods (e.g. 1960s to 1980s) to mitigate crises. This is important because different eras have different characteristics, which will affect the optimal policies chosen to fight crises. 


\section{CONCLUSION}

We assessed the early warning indicators of crises and the optimal policies implemented to overcome crises. Using meta-analysis on 72 studies, we document interesting findings. We find that most studies used the EMPI index approach to establish the early warning indicators of crises. The most used combination of EMPI components are the exchange rate and foreign exchange reserves, determined using the inverse of the indicators as weights. The most used threshold coefficient of EMPI component is 1.5 standard deviations, while a period is categorized as in a crisis if the calculated EMPI value exceeds the standardized threshold level. In addition, we find that the commonly used leading indicators of crises are external factors, such as exchange rates, foreign exchange reserves, current accounts, and external debt and internal factors such as interest rates, bank credit, and nonperforming loans.

When we group countries by the level of development, we find that in both developed and developing countries, the exchange rate is the common leading indicator of crises. In developed countries, the next most dominant indicator of crises is the interest rate, implying that markets are more sensitive to interest rate policies in developed countries during crises. Meanwhile, in developing countries, the role of other external sector variables, such as foreign exchange reserves, current accounts, and external debt dynamics, are becoming more relevant as crisis predictors. In developing countries, the interest rate is not an effective early warning predictor of crises, since capital flight concerns are unavoidable and herding behavior on the interest rate dynamics originating from developed economies is evident. Hence, in developing countries, concerns regarding the performance of variables that can induce global market confidence, such as the performance of foreign exchange, and foreign exchange reserves, current accounts, and external debt, are more relevant. This evidence aligns with the finding that policies addressing external sector performance are preferable in developing countries in mitigating crises.

Although there are similarities in crisis mitigation policies adopted by countries, which are monetary and fiscal policies, there are clear differences on other policies across country groupings. Developing countries rely more on the external sector policies, such as foreign exchange reserves, exchange rates, and current account balance management, whereas developed countries depend more on guarantees, macro-prudential measures, and international assistance, in order to restore domestic financing capability. In this regard, the policy recommendation for developing countries are related to policies to induce better external sector performance. Such policies are essential in anticipating and mitigating crises, since they will subsequently help restore global market confidence and raise market preference for holding domestic financial assets. Furthermore, the novelty of the findings in this study can be exploited to identify early or leading indicators of crisis, and to build appropriate crisis mitigating policies. Our findings can also be utilized to enhance the development of early warning systems, business cycle analysis, and various types of surveys, which are routinely used by policymakers in mapping current and expected economic conditions. 


\section{Acknowledgment}

The conclusion, interpretation, and opinion expressed in this paper are those of the researchers and not necessarily represent the views of Central Bank of Indonesia. The authors would like to acknowledge insightful comments and support from Prof. Dr. Insukindro, MA and Prof. Dr. Ir. Noer Azam Achsani, MS, and Miftakhul Khoir Nur Rahmawadi, BEc.

\section{REFERENCES}

Al-Assaf, G. (2017). An Early Warning System for Currency Crisis: A Comparative. International Journal of Economics and Financial Issues, 7, 43-50.

Allegret, J.-P., \& Allegret-Sallenave, A. (2018). The Role of International Reserves Holding in Buffering External Shocks. Applied Economics, Taylor \& Francis (Routledge), 50, 3128-3147.

Babecky, J., Komarek, L., \& Komarkova, Z. (2013). Financial Integration at Times of Financial Instability. Czech Journal of Economics and Finance (Finance a uver), $63,25-45$.

Basu, A. (2017). How to Conduct Meta-analysis: a Basic Tutorial. PeerJ Preprints 5.

Bech, M. L., Gambacorta, L., \& Kharroubi, E. (2012). Monetary Policy in a Downturn: Are Financial Crises Special?. International Finance, 17, 99-119.

Berg, A., \& Pattillo, C. (1998). Are Currency Crises Predictable? A Test. IMF Working Papers 98/154.

Bodea, C., Houle, C., \& Kim, H. (2019). Do Financial Crises increase Income Inequality?. Available at SSRN: https://ssrn.com/abstract=3486470

Boissay, F., Collard, F., \& Smets, F. (2016). Booms and Banking Crises. Journal of Political Economy, 124(2), 489-538.

Bom, P. R., \& Ligthart, J. (2008). How Productive is Public Capital? A MetaAnalysis. CESifo Working Paper Series No. 2206.

Bonga-Bonga, L. ( 2017). Fiscal policy, Monetary policy and External Imbalances: Cross-country evidence from Africa's three largest economies (Nigeria, South Africa and Egypt). MPRA Paper 79490.

Boorman, J. (2009). The Current Financial Crisis: Its Origins, Its Impact, and the Needed Policy Response. Global Journal of Emerging Market Economies, 1, 127135.

Bucevska, V. (2011). An Analysis of Financial Crisis by an Early Warning System Model: The case of the EU candidate countries . Business and Economic Horizons, 4, 13-26

Caggiano, G., Calice, P., \& Leonida, L. (2013). Early Warning Systems and Systemic Banking Crises in Low Income Countries: A Multinomial Logit Approach. Journal of Banking \& Finance, 47(C), 258-269.

Caramazza, F., Ricci, L., \& Salgado, R. (2000). Trade and Financial Contagion in Currency Crises. IMF Working Papers 2000/055.

Catão, L. A., \& Milesi-Ferrett, G. M. (2012). External Liabilities and Crisis Risk. Draft Paper IMF, 28 April.

Choi, G. (2002). An Early Warning System for Contagious Currency Crisis. KIF Financial Economics Series. 
Chowdhury, L. S., \& Afzal , M. N. (2015). The Effectiveness of Monetary Policy and Fiscal Policy in Bangladesh. Journal of Applied Business and Economics 17(1) 78-85.

Christiano, L., Gust, C., \& Roldos, J. (2004). Monetary Policy in a Financial Crisis. Journal of Economic Theory, 119, 64-103.

Claessens, S., \& Kose, A. (2013). Financial Crises: Explanations, Types, and Implications. IMF Working Papers 2013/28.

Claessens , S., \& R. Ghosh, S. (2013). Capital Flow Volatility and Systemic Risk in Emerging Markets: The Policy Toolkit. In O. Canuto, \& S. Ghosh (Eds.), Dealing with the Challenges of Macro Financial Linkages in Emerging Markets. The World Bank.

Comelli, F. (2014). Comparing the Performance of Logit and Probit: Early Warning Systems for Currency Crises in Emerging Market Economies. IMF Working Papers 14/65.

Cooper, H., Hedges, L. V., \& Valentine, J. C. ( 2009). The Handbook of Research Synthesis And Meta-Analysis. New York: The Russell Sage Foundation.

Corsetti, G., Pesenti, P., \& Roubini, N. (1998). Paper Tigers? A Model of the Asian Crisis. NBER Working Papers 6783.

Crispolti , V., \& Tsibouris, G. (2012). International Reserves in Low Income Countries:Have They Served as Buffers? . IMF Research Paper Series.

Dominguez, K., Hashimoto, Y., \& Ito, T. (2011). International Reserves and the Global Financial Crisis. NBER Working Papers 17362.

Dullien, S., Kotte, D., Márquez, A., \& Priewe, J. (2010). The Financial and Economic Crisis of 2008-2009 and Developing Countries. United Nations Publication.

Edison, H. (2000). Do Indicators Of Financial Crises Work? An Evaluation of an Early Warning System. International Finance Discussion Papers 675.

Edison, H. J., Levine, R., Ricci, L., \& Sløk, T. (2002). International Financial Intergration and Economic Growth. IMF Working Paper, 749-776.

Edmonds, T., Webb, D., \& Long, R. (2011). The Economic Crisis: Policy Responses. Retrieved from House of Common Library: https://commonslibrary.parliament. uk/research-briefings/sn04968/

Egger, M., \& Smith, G. D. (1997). Meta Analysis: Potentials and Promise. BMJ , 315, 1371-1374

Eichengreen, B., Rose, A. K., \& Wyplosz, C. (1994). Speculative Attacks on Pegged Exchange Rate: an Empirical Exploration with Special Reference to the European Monetary System. NBER Working Papers 4898.

Eichengreen, B., Rose, A., \& Wyplosz, C. (1997). Contagious Currency Crises. NBER Working Ppaers 5681

Eichengreen, B., Hausmann, R., \& Panizza, U. (2003). The Pain of Original Sin. in Eichengreen et al., Other People's Money - Debt Denomination and Financial Instability in Emerging Market Economies, University of Chicago Press.

Esquivel, G., \& B, F. L. (1998). Explaining Currency Crises. John F. Kennedy Faculty Research Working Paper Series R98-07

Finckh, A., \& Tramèr, M. (2008). Primer: Strengths and weaknesses of metaanalysis. Nature Clinical Practice Rheumatology, 4, 146-152.

Frankel, J. A., \& Rose, A. K. (1996). Currency Crashes In Emerging Markets: An Empirical Treatment. International Finance Discussion Papers 534. 
Frankel, J., \& Saravelos, G. (2011). Can Leading Indicators Assess Country Vulnerability? Evidence from the 2008-09 Global Financial Crisis. HKS Faculty Research Working Paper Series RWP11-024,John F. Kennedy School of Government, Harvard University.

Fratzscher, M. (2002). On Currency Crises and Contagion. ECB Working Paper Series 139.

Furceri , D., \& Mourougane , A. (2009). Financial Crisis: Past Lessons and Policy Implications. OECD Economics Department Working Papers 668, OECD Publishing.

Glick, R., \& Rose, A. (1998). Contagion and Trade: Why Are Currency Crises Regional? Journal of International Money and Finance, 18, 603-617.

Goldstein, M., Kaminsky,, G., \& Reinhart, C. (2000). Assessing Financial Vulnerability, an Early Warning System for Emerging Markets: Introduction. MPRA Paper 13629.

Goldfajn, I., \& Valdes, R. O. (1997). Are Currency Crises Predictable?. European Economic Review, 42, 873-885.

Haidich, A. B. (2010). Meta-analysis in Medical Research. Hippokratia,14, 29-37.

Hlaing, S. W., \& Kakinaka, M. (2018). Financial Crisis and Financial Policy Reform: Crisis Origins and Policy Dimensions. European Journal of Political Economy, 55, 224-243.

Hmili, R., \& Bouraoui, T. (2015). Early Warning Indicators of Banking Crisis in. Expert Journal of Finance, 3, 1-8.

Hoffman, J. (2015). Biostatistiks for Medical and Biomedical Practitioners. USA: Academic Press.

Jacobs, J., Kuper, G., \& Lestano. (2005). Currency crises in Asia: A multivariate logit approach. CCSO Working Papers 200506.

Juhro, S. M., \& Iyke, B. N. (2019). Monetary Policy and Financial Conditions in Indonesia. Bulletin of Monetary Economics and Banking, 21, 283-302.

Kamin, S. B., \& Babson, O. D. (1999). The Contribution Of Domestic And External Factors To Latin American Devaluation Crises: an Early Warning System Approach. International Finance Discussion Papers 645.

Kamin, S., Schindler, J., \& Samuel, S. (2007). The Contribution of Domestic and External Factors to Emerging Market Currency Crises: an Early Warning Systems Approach. International Journal of Finance EEconomics, 12, 317-336.

Kaminsky, G. L., \& Reinhart, C. (1999). The Twin Crises: The Causes of Banking and Balance-of-Payments Problems. American Economic Review , 89, 473-500.

Kaminsky, G., Lizondo, S., \& Reinhart, C. (1998). Leading Indicators of Currency Crises. IMF Staff Papers, 45, 1-48.

Karmarkar, Y., \& Vani, S. (2014). Early Warning Signal System for Economic Crisis: a Threshold and Indicators Approach. Pacific Business Review International, 6, 60-70.

Kim, Y. (2000). Causes of capital flows in developing countries. Journal of International Money and Finance, 19, 235-253.

Kose, M., Nagle, P., Ohnsorge, F., \& Sugawara, N. (2019). Global Waves of Debt: What Goes up Must Come Down? In Global Waves of Debt: Causes and Consequences (pp. 57-107). World Bank Group.

Laeven, L., \& Valencia, F. (2018). Systemic Banking Crises Revisited. IMF Working Paper 18/206. 
Lipsey, M., \& Wilson, D. (2001). Practical meta-analysis. Sage Publication.

Lopez-Mejia, A. (1999). Large Capital Flows: A Survey of the Causes, Consequences, and Policy Responses. IMF Working Paper 99/17.

Mack, O., Khare, A., Krämer, A., \& Burgartz, T. (2016). Managing in a VUCA World (1 ed.). New York: Springer International Publishing.

Milesi-Ferretti, G. M., \& Razin, A. (1998). Current Account Reversals and Currency Crises: Empirical Regularities. IMF Working Papers 1998/89.

Mishkin, F. (2001). Financial Policies and the Prevention of Financial Crises in Emerging Market Countries. NBER Working Paper 8087.

Moreno, R. (1999). Did a Boom in Money and Credit Precede East Asia's Recent Currency Crisis? Economic Review Federal Reserves Bank of San Francisco, 23-41

Nickel, C., \& Vanbsteenkiste, I. (2008). Fiscal policies, the Current Account and Ricardian Equivalence. European Central Bank Working Paper Series 935.

Obstfeld, M. (1994). Risk-taking, Global Diversification, and Growth. American Economic Review, 84(5), 1310-1329.

OECD. (2011). Future Global Shocks: Improving Risk Governance. OECD Publishing.

OECD. (2011). The Performance of the OECD's Composite Leading Indicator During the 2007 Financial Crisis. The Statistik Newsletter No 51. OECD Statistics Directorate.

Padhan, R., \& Prabheesh, K. (2019). Effectiveness of Early Warning Models: A Critical Review and New Agenda for Future Directions . Bulletin of Monetary Economics and Banking, 22 ,457-484.

Panetta, F., Faeh, T., Grande, G., Ho, C., King, M., Levy, A., Signoretti, F., Taboga, M., Zaghini, A. (2009). An Assessment of Financial Sector Rescue Programmes. Bank of Italy Occasional Papers No 47.

Phan, D. H., Iyke, B. N., Sharma, S. S., \& Affandi, Y. (2020). Economic policy uncertainty and financial stability-Is there a relation?. Economic Modelling.

Prabheesh, K., Anglingkusumo, R., \& Juhro, S. (2020). The Dynamics of Global Financial Cycle and Domestic Economic Cycles: Evidence from India and Indonesia. Economic Modelling, In Press.

Ramskogler, P. (2015). Tracing the Origins of the Financial Crisis. OECD Journal: Financial Market Trends, 2014, 47-61.

Reinhart, C., \& Rogoff, K. (2009). The Aftermath of Financial Crises. NBER Working Papers 14656.

Reinhart, C., \& S. Rogoff, K. (2008). This Time is Different: a Panoramic View of Eight Centuries of Financial Crisis. NBER Working Papers 13882.

Sachs, J., Tornell, A., \& Velasco, A. (1996). Financial Crises In Emerging Markets: The Lessons From 1995. NBER Working Papers 5576.

Schnatz, B. (1998). Macroeconomic Determinants of Currency Turbulences in Emerging Markets. Deutsche Bundesbank Discussion Paper Series 1: Economic Studies No 3/98.

Shelby, L. B., \& Vaske, J. J. (2008). Understanding Meta-Analysis: A Review of the Methodological Literatur, Leisure Sciences: An Interdisciplinary Journal. 30(2), 96-110.

Stanley, T. D. (2001). Wheat from Chaff: Meta-analysis as Quantitative Literature Review. Journal of Economic Perspectives, 15, 131-150. 
Stavárek, D., Řepková, I., \& Gajdošová, K. (2011). Theory of financial integration and achievements in the European Union. Munich Personal RePEc Archive.

Supriyadi, A. (2014). External Vulnerability Indicators: The Case of Indonesia. IFC Bulletins chapters, in: Bank for International Settlements (ed.),Indicators to support monetary and financial stability analysis: data sources and statistical methodologies, Volume 39.

Taylor, A. M. (2013). External Imbalances and Financial Crises. IMF Working Papers $13 / 260$.

Tornell, A. (1999). Common Fundamentals In The Tequila And Asian Crises. NBER Working Papers 7139.

The Stiglitz Commission. (2010). The Stiglitz Report: Reforming the International Monetary and Financial Systems in the Wake of the Global Crisis. New York: The New Press.

UNCTAD . (2010). The Least Developed Countries Report 2010. New York and Geneva: United Nations Publishing.

United Nation. (2018). World Economic Situation and Prospects 2018. New York: United Nations Publishing.

Warjiyo, P. (2015). Indonesia: Global Spillover and Policy Response. Paper presented at the Asia Economic Policy Conference (AEPC), Federal Reserve Bank of San Francisco (FRBSF), November.

Warjiyo, P., \& Juhro, S. M. (2016). Kebijakan Bank Sentral: Teori dan Praktik. Jakarta: Rajawali Grafindo

Woo, W. T., Carleton, P. D., \& Rosario, B. P. (2000). The Unorthodox Origins of the Asian Currency Crisis: Evidence from Logit Estimation. ASEAN Economic Bulletin, 17(2), 120-134.

World Bank. (2009).Global Monitoring Report 2009: a Development Emergency. Washington: The World Bank Publication

Wróblewski, M. (2008). International Monetary Fund and financial crises in the global economy . GARNET Working Paper 40/2008.

Young, B. (2014). Financial Crisis: Causes, Policy Responses, Future Challenges. Luxembourg: the European Union Publication.

Zhuang, J., \& Dowling, J. (2002). Causes of the 1997 Asian Financial Crisis: What Can an Early Warning System Model Tell Us?. ADB Economics Working Paper Series. 